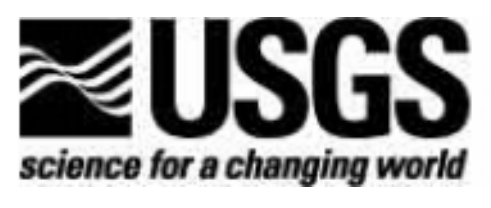

\title{
Relative Coastal Change-Potential Assessment of Glacier Bay National Park and Preserve
}

By Elizabeth A. Pendleton, E. Robert Thieler, and S. Jeffress Williams

U.S. Geological Survey Open-File Report 2005-1247

U.S. Department of the Interior

U.S. Geological Survey 


\section{U.S. Department of the Interior \\ Dirk Kempthorne, Secretary}

\section{U.S. Geological Survey \\ Mike D. Myers, Acting Director}

\section{U.S. Geological Survey, Reston, Virginia 2006}

For product and ordering information:

World Wide Web: http://www.usgs.gov/pubprod

Telephone: 1-888-ASK-USGS

For more information on the USGS - the Federal source for science about the Earth, its natural and living resources, natural hazards, and the environment:

World Wide Web: http://www.usgs.gov

Telephone: 1-888-ASK-USGS

See the National Park Unit Coastal Vulnerability study at http://woodshole.er.usgs.gov/projectpages/nps-cvi/,

the National Coastal Vulnerability study at http://woodshole.er.usgs.gov/project-pages/cvi/, or view the USGS online fact sheet for this project in PDF format at http://pubs.usgs.gov/fs/fs095-02/. Glacier Bay National Park and Preserve Web pages are at http://www.nps.gov/glba/index.htm.

For contacts, see project page at http://woodshole.er.usgs.gov/project-pages/nps-cvi/ Telephone: 508-548-8700

Rebecca Beavers

National Park Service

Natural Resource Program Center

Geologic Resources Division

P.0. Box 25287

Denver, C0 80225-0287

Rebecca_Beavers@nps.gov

Telephone: 303-987-6945

Suggested citation:

Pendleton, E.A., Thieler, E.R. and Williams, S.J., 2006, Coastal vulnerability assessment of Glacier Bay National Park to sea-level rise: U.S. Geological Survey Open-File Report 20051247, Web Only. Available online at URL: pubs.usgs.gov/of/2005/1247.

Any use of trade, product, or firm names is for descriptive purposes only and does not imply endorsement by the U.S. Government.

Although this report is in the public domain, permission must be secured from the individual copyright owners to reproduce any copyrighted material contained within this report. 


\section{Contents}

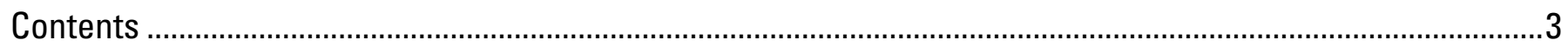

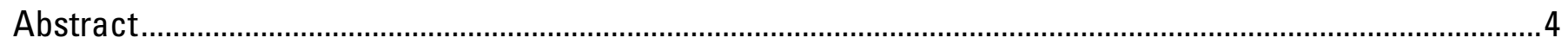

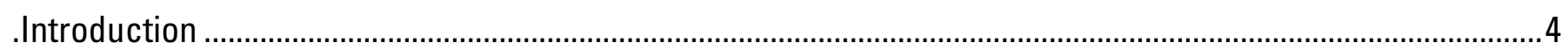

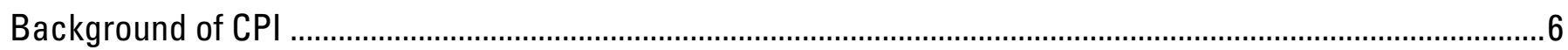

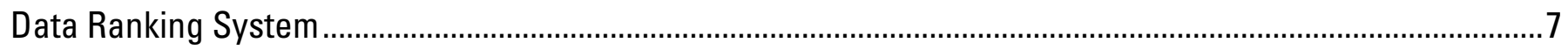

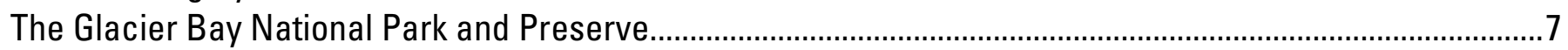

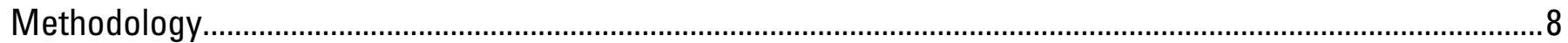

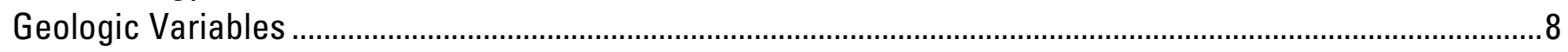

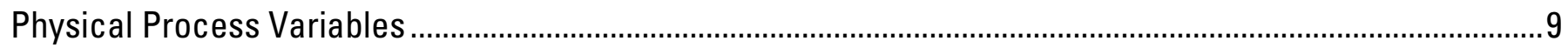

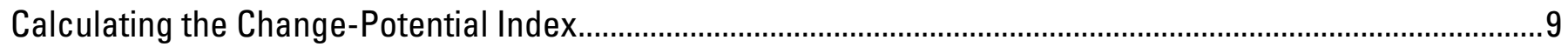

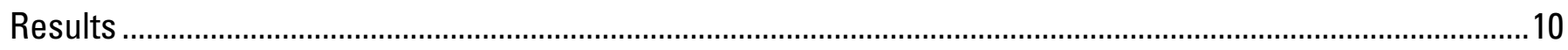

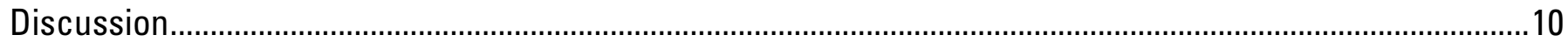

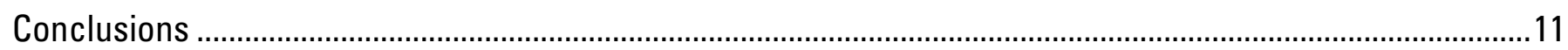

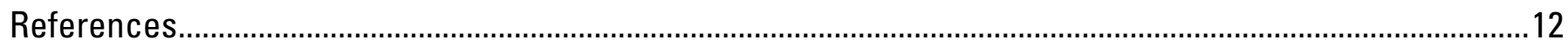

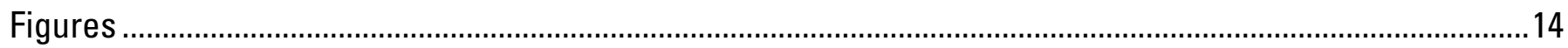

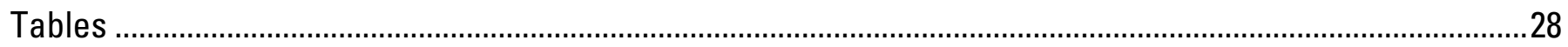




\title{
Relative Coastal Change-Potential Assessment of Glacier Bay National Park and Preserve
}

\author{
Elizabeth A. Pendleton, E. Robert Thieler, and S. Jeffress Williams
}

\begin{abstract}
A change-potential index (CPI) was used to map the relative coastal change-potential of the shoreline to future sea-level fluctuation within Glacier Bay National Park and Preserve (GBNPP) in southeastern Alaska. The CPI ranks the following in terms of their physical contribution to coastal change: geomorphology, regional coastal slope, rate of relative sea-level change, historical shoreline change rates, mean tidal range and mean significant wave height. The rankings for each input variable were combined, and an index value calculated for 1-minute grid cells covering the park. The CPI highlights those regions where the physical effects of sea-level and coastal change might be the greatest. This approach combines the coastal system's potential for change with its natural ability to adapt to changing environmental conditions, yielding a quantitative, although relative, measure of the park's natural susceptibility to the effects of sea-level variation. The CPI provides an objective method for evaluation and long-term planning by scientists and park managers. The CPI was developed from a Coastal Vulnerability Index (CVI) typically applied to coastlines experiencing long-term sea-level rise. The CPI is modified from the CVI and applied to the emergent coast of GBNPP to understand the limits of applying this type of assessment method in a variety of sea level settings. GBNPP consists of sand and gravel beaches, rock cliffs, calving glaciers, mudflats, and alluvial fans. The areas within GBNPP that are likely to be most susceptible to coastal change as a result of sea-level change are tidewater glaciers and outer coast shorelines of unconsolidated sediment where wave energy is highest and the regional coastal slope is shallowest.
\end{abstract}

\section{.Introduction}

The National Park Service (NPS) is responsible for managing nearly $12,000 \mathrm{~km}(7,500$ miles) of shoreline along oceans and lakes. In 2001, the U.S. Geological Survey (USGS), in partnership with the NPS Geologic Resources Division, began conducting assessments of the effects of future sea-level change by creating maps to assist NPS in managing its valuable coastal resources. This report presents the results of a potential for change assessment for GBNPP, highlighting areas that are likely to be most affected by future sea level and coastal change.

Global sea level has risen approximately 18 centimeters ( 7.1 inches) in the past century (Douglas, 1997). Climate models predict an additional rise of $48 \mathrm{~cm}$ (18.9 in.) by 2100 (IPCC, 2002), which is more than double the rate of rise for the 20th century. Sea level is rising relative to the land surface in more than 74 percent of the locations where there are water level recording stations worldwide (fig. 1). In the United States more than 85 percent of the coastline is experiencing a relative increase in sea level (Permanent Service for Mean Sea Level, http://www.nbi.ac.uk/psmsl/datainfo/rlr.trends). Glacier Bay and most of southeastern Alaska are 
among the small percentage of the world's coastline experiencing a fall in relative sea-level due to uplift of the land through glacial rebound and isostatic adjustments. Potential coastal impacts of sea-level fall include dewatering and water quality reduction in wetlands and estuaries, decreases in harborage area, channel shoaling, increased dredging needs, subaerial exposure of polluted marine sediments, gullies and erosion near rivers and streams associated with base-level changes, and habitat loss. The Great Lakes and the Dead Sea are examples of areas where resource managers must try to mitigate impacts associated with falls in water levels (US Global Change Research Program, 2000; Hassan, and Klein, 1999).

Predicted accelerated global sea-level rise has generated a need in coastal geology to determine the likely response of a coastline to sea-level change. An accurate and quantitative approach to predicting coastal change is difficult to establish. Even the kinds of data necessary to predict shoreline response are the subject of scientific debate. A number of predictive approaches that primarily focus on sea-level rise impacts have been proposed (National Research Council, 1990 and 1995), including:

1. extrapolation of historical data (e.g., coastal erosion rates),

2. static inundation modeling,

3. application of a simple geometric model (e.g., the Bruun Rule),

4. application of a sediment dynamics/budget model, or

5. Monte Carlo (probabilistic) simulation based on parameterized physical

6. forcing variables.

However, each of these approaches has inadequacies or can be invalid for certain applications (National Research Council, 1990). Additionally, shoreline response to sea level is further complicated by human modification of the natural coast such as beach nourishment projects, and engineered structures such as seawalls, revetments, groins, and jetties. Understanding how a natural or modified coast will respond to sea-level change is essential to preserving coastal resources.

The primary challenge in predicting shoreline response to sea-level change is quantifying the important variables that contribute to coastal evolution in a given area. In order to address the multi-faceted task of predicting sea-level change impact, the USGS has implemented a methodology to identify areas that may be most likely to experience coastal change (Thieler and Hammar-Klose, 1999). This technique known as the Coastal Vulnerability Index (CVI) utilizes different ranges of vulnerability (low to very high) to describe a coast's susceptibility to physical change as sea level rises. The coastal vulnerability index was modified for coasts where sea level is falling and a slightly different index was developed, the coastal change-potential index (CPI). The CPI used here focuses on the same six variables as the CVI that strongly influence coastal evolution:

1. Geomorphology

2. Historical shoreline change rate

3. Regional coastal slope

4. Relative sea-level change

5. Mean significant wave height

6. Mean tidal range

These variables can be divided into two groups: 1) geologic variables and 2) physical process variables. The geologic variables are geomorphology, historic shoreline change rate, and coastal slope; they account for a shoreline's relative resistance to erosion, long-term 
erosion/accretion trend, and its susceptibility to flooding or subaerial exposure, respectively. The physical process variables include significant wave height, tidal range, and sea-level change, all of which contribute to the process-induced changes on a particular section of coastline over time scales from hours to centuries. A relatively simple change-potential ranking system (table 1) allows the six variables to be incorporated into an equation that produces a change-potential index (CPI). The CPI can be used by scientists and park managers to evaluate the likelihood that physical change may occur along a shoreline as sea level continues to change. Additionally, NPS staff will be able to incorporate information provided by this change-potential assessment technique into general management plans.

\section{Background of CPI}

The Change-Potential Index (CPI) for assessing susceptibility to coastal change associated with sea level fall was derived from a similar methodology called the Coastal Vulnerability Index (CVI), which was developed to highlight the vulnerability of a coast to sea-level rise impacts (Thieler and Hammar-Klose, 1999). Potential impacts associated with sea-level rise include shoreline erosion, saltwater intrusion into groundwater aquifers, inundation of wetlands and estuaries, and threats to cultural and historic resources as well as infrastructure. Impacts from sealevel fall in an area like southeastern Alaska could include grounding of tidewater glaciers, dewatering of wetland areas, decreases in harborage area, channel shoaling, stream and river mouth erosion, and habitat loss. A goal of the USGS/NPS cooperative project was to apply the CVI methodology in a variety of sea-level settings, and GBNPP was selected as a location where relative sea-level is falling. Because the impacts associated with sea-level fall are different from impacts associated with sea-level rise, a slightly different index was developed to differentiate assessments in areas with falling sea-level from areas experiencing sea-level rise. In this study, we considered that impacts are often evaluated from a human perspective and a human connection to the coast. Threats to infrastructure, for example, are a major concern along coastlines that are experiencing sea-level rise. Alternatively in areas where sea-level is falling, the potential subaerial exposure of polluted marine sediments may be a primary concern. For the purposes of this cooperative project, we chose to reserve the word 'vulnerability' for coastlines that may succumb to loss of land, infrastructure, or natural and cultural resources as a result of sea level rise.

Alternatively, for areas where sea level is falling and associated impacts are not as well-understood or researched, we address the likelihood that coastal change may occur without assigning a subjective term such as risk, hazard, or vulnerability.

One assumption that is made in order to apply the CPI method to an emerging coast is, that independent of the net movement of sea level relative to the land surface, the variables that are most important to coastal change and shoreline evolution will be the same. That is, the six variables defined in the CPI methodology will be important for both submerging (experiencing relative sealevel rise) and emerging (experiencing relative sea-level fall) coastlines. Since the CPI is designed to highlight change-potential based on variables that are common to almost all coasts without directly indicating a physical effect, it should be amenable to application in a variety of geologic settings. Although this methodology can be applied anywhere that physical change is likely to occur as a result of changing sea-level, the physical changes that may occur are not addressed and should be considered by planners in the context of resources utilization and preservation. This report illustrates that CPI methodology can be applied along the southeastern coast of Alaska. The usefulness of the data for planning purposes, however, will be a function of the nature of potential environmental change and whether such change is desirable from a resource management perspective . 


\section{Data Ranking System}

Table 1 shows the six variables described in the Introduction, which include both quantitative and qualitative information. The five quantitative variables are assigned a changepotential ranking based on their actual values, whereas the non-numerical geomorphology variable is ranked qualitatively according to the relative susceptibility of a given landform to physical change. Shoreline change-potential is estimated when vector shorelines are not available for determining rate of shoreline change. Rock cliff areas are assigned low shoreline change-potential, because rock cliffs are not likely to experience significant erosion or accretion annually. Unconsolidated sediments within fjords are classified as moderate shoreline change-potential. Beaches along the open coast and areas where glaciers reached at or near the shoreline are classified as high shoreline change-potential. Regional coastal slopes range from very high changepotential, $<4.59$ percent, to very low change-potential at values $>14.7$ percent. The rate of relative sea-level change is ranked such that no change in sea-level $(0 \mathrm{~mm} / \mathrm{yr})$ up to the modern rate of eustatic rise $(1.8 \mathrm{~mm} / \mathrm{yr})$ as very low change-potential. Since the global or "background" rate is common to all shorelines, the sea-level ranking reflects primarily local to regional isostatic or tectonic adjustment. Mean wave height contributions to change-potential range from very low $(<1.1$ $\mathrm{m})$ to very high $(>2.6 \mathrm{~m})$. Tidal range is ranked such that microtidal $(>1 \mathrm{~m})$ coasts are very high change-potential and macrotidal $(>6 \mathrm{~m})$ coasts are very low change-potential.

\section{The Glacier Bay National Park and Preserve}

Glacier Bay National Park and Preserve lies along the southeastern coast of Alaska within a geologic area known as the Alexander Archipelago (fig. 2). The Alexander terrane was made up of Paleozoic ocean trench sediments, volcanic rocks, limestones, and cherts when it welded to North America during the mid-Jurassic. Since that time the Alexander terrane has experienced igneous intrusions, broad metamorphosis with recrystallization, and large-scale faulting (as much as 200 $\mathrm{km}$ ), which has resulted in a very complex geologic framework for southeast Alaska (Connor and O'Haire, 1988). In addition to the tectonic activity associated with accreting terranes, the advance and retreat of glacier ice throughout the Pleistocene (fig. 3) has caused drastic sea-level fluctuations along the coast of the Gulf of Alaska due to isostasy. Alpine glaciers may have appeared in the mountains of southern Alaska between 10 and 13 million years ago and many of these areas have remained ice covered for at least the past five million years (Connor and O'Haire, 1988). Deep valleys carved by glaciers during glacial maxima are now flooded, creating irregular shorelines such as the arms of Glacier Bay. Glacier Bay itself was completely filled with ice during the Little Ice Age (1400 - $1750 \mathrm{AD})$, and as the glaciers began to retreat up the bay a large outwash plain was deposited where the town of Gustavus is now located. Today GBNPP has 11 tidewater glaciers that are supplying ice and sediment directly to the coast where waves and tides further modify this rugged coastline creating a variety of geomorphology types including sand, gravel, and boulder beaches, rock cliffs and platforms, mud flats, and modified alluvial and glacial deposits.

An aspect that makes Glacier Bay and most of southeastern Alaska unique when compared to the majority of the world's coastline is that this region is experiencing a fall in relative sea-level due to uplift of the land through glacial rebound and isostatic adjustments (fig. 1). Essentially, the area is emerging at a faster rate than global sea-level $(1.8 \mathrm{~mm} / \mathrm{yr})$ is rising. Parts of Glacier Bay are experiencing some of the highest rates of uplift $(28 \mathrm{~mm} / \mathrm{yr})$ in southeastern Alaska (fig. 4). Uplift rates are determined from raised shorelines, GPS measurements, water level recorders, and ice load and viscoelastic earth models (Larsen and others, 2003; Larsen and others, 2005). 


\section{Methodology}

In order to develop a database for a park-wide assessment of coastal change-potential, data for each of the six variables mentioned above were gathered from state and federal agencies (table 2). The database is based on that used by Thieler and Hammar-Klose (1999) and loosely follows an earlier database developed by Gornitz and White (1992). A comparable assessment of the sensitivity of the Canadian coast to sea-level change is presented by Shaw and others (1998).

The database was constructed using a 1:63,360-scale shoreline (USGS) for GBNPP and a coastline based on nautical charts of varying scale (NOAA) (Geiselman, 1997). Data for each of the six variables (geomorphology, shoreline change, coastal slope, relative sea-level change, significant wave height, and tidal range) were added to a shoreline attribute table that was divided into 1minute (approximately $1.5 \mathrm{~km}$ ) segments (fig. 5). Next each variable in each shore segment was assigned a change-potential value from 1-5 (1 is very low change-potential, 5 is very high changepotential) based on the possible magnitude of its contribution to physical changes on the coast as sea level changes (table 1).

\section{Geologic Variables}

The geomorphology variable expresses the relative erodibility of different landform types (table 1). These data were derived using surficial geology, ice extent, topographic maps and oblique aerial photography. The geology and ice extent information are available on the Glacier Bay Ecosystem GIS CD-ROM (Geiselman and others, 1997). The oblique aerial photos were collected during a field visit (fig. 6 A-I). Descriptions in the book Living with the Coast of Alaska (Mason and others, 1997) were also used to help inform the geomorphologic classification. GBNPP contains several geomorphologic types, including low to very low change-potential rock cliffs, moderate change-potential alluvial and glacial deposits, high change-potential gravel and sand beaches, and very high change-potential tidewater glacier termini (fig. $6 \mathrm{~A}-\mathrm{I}$ and fig. 7).

Shoreline change-potential (erosion/accretion) for GBNPP were estimated using oblique aerial photos and an interview with an expert in shoreline dynamics along the Gulf of Alaska (B. Molnia, personal communication, Nov., 2004). Historical digital vector shorelines typically used to calculate a rate of shoreline change were not available for Glacier Bay, so the oblique aerial photos were used in conjunction with regional expertise. Because shoreline change-potential data were derived qualitatively, the categories for shoreline change were limited to high, moderate, and low. Shoreline change-potential was not assigned to the very low or very high categories. Rock cliff areas were assigned low shoreline change-potential, because rock cliffs are not likely to experience significant erosion or accretion annually. Unconsolidated sediments were generally classified as moderate shoreline change-potential. Areas within Glacier Bay where glaciers reached at or near the shoreline were classified as high shoreline change-potential. Shoreline change-potential for GBNPP range from low change-potential (areas not likely to experience significant shoreline change annually) to high change-potential (areas where shoreline change will likely occur within one year) (table 1).Two areas within the park have been experiencing historic accretion: Taylor Bay and the western edge of the Gustavus outwash plain (B. Molnia, personal communication, Nov., 2004). The outer coast north of Icy Point would have the potential for a trend of long-term shoreline erosion due to high wave energy and gravel beaches; however periodic tectonic events $(\sim$ 1 event/ 100 years) result in an overall stable shoreline position (Molnia, 1986).

Regional coastal slope is an indication of the relative change-potential to inundation and the potential rapidity of shoreline retreat because low-sloping coastal regions should retreat faster than steeper regions (Pilkey and Davis, 1987). The regional slope of the coastal zone was 
calculated from a grid of topographic and bathymetric elevations extending $10 \mathrm{~km}$ landward and seaward of the shoreline. Elevation data were obtained from the National Geophysical Data Center (NGDC) as gridded topographic and bathymetric elevations at 0.1-meter vertical resolution for 1minute grid cells, and higher resolution bathymetric and topographic data on the Glacier Bay Ecosystem GIS CD-ROM (Geiselman, 1997). Regional coastal slopes for Glacier Bay fall within the very low to very high change-potential category $(<4.55 \%->14.7 \%)$ (fig. 9$)$.

\section{Physical Process Variables}

The relative sea-level change variable is derived from the change in annual mean water elevation over time as measured at tide gauge stations along the coast. The rate of sea-level change for Yakutat, AK is $-5.75+/-0.27 \mathrm{~mm} / \mathrm{yr}$ based on 60 years of data (Zervas, 2001). This variable inherently includes both eustatic sea-level change as well as regional sea-level change due to isostatic and tectonic adjustments of the land surface. Relative sea-level change data are a historical record, and thus portray only the recent sea-level trend ( $<150$ years). Relative sea-level change for GBNPP falls within the very high change-potential category based on water elevation data at Yakutat, AK (fig. 10). A higher resolution study of uplift rates not including sea level change along southeast Alaska was conducted using the tide records mentioned here as well as GPS measurements, raised shorelines, and earth models (Larsen and others, 2003; Larson and others, 2005).

Mean significant wave height is used here as a proxy for wave energy which drives coastal sediment transport. Wave energy is directly related to wave height

$E=1 / 8 \quad \rho g H^{2}$

where $\mathrm{E}$ is energy density, $\mathrm{H}$ is wave height, $\rho$ is water density and $\mathrm{g}$ is acceleration due to gravity. Thus, the ability to mobilize and transport coastal sediments is a function of wave height squared. Historical measured significant wave height values were available for eastern Gulf of Alaska through the National Data Buoy Center. Station 46083 was located $170 \mathrm{~km}$ southeast of Yakutat, AK and average mean significant wave heights were $3.55 \mathrm{~m}$ (very high change-potential). Wave heights for Icy Straits were determined from NOAA nautical charts (low change-potential). While wave heights within Glacier Bay were assumed to be within the very low change-potential category because of the limited fetch length. Mean significant wave heights within GBNPP ranged from very low to very high change-potential (fig. 11).

Tidal range is linked to both permanent and episodic inundation hazards. Tide range data were obtained from NOAA/NOS published benchmarks from Graves Harbor, Dixon Harbor, Lituya Bay, Dry Bay, Lemesurier Island Light, Bartlett Cove, Willoughby Island, Muir Inlet, and Composite Island (NOAA, 2005). Mean tidal ranges fell between 2.31 and $4.25 \mathrm{~m}$, therefore classified as moderate change-potential (2.0 - 4.0 meters) and low change-potential (4.01 - 6.0 meters) with respect to tidal range (fig. 12).

\section{Calculating the Change-Potential Index}

The coastal change-potential index (CPI) employed here is the same as that used in Thieler and Hammar-Klose (1999) and is similar to that used in Gornitz and others (1994), as well as to the sensitivity index employed by Shaw and others (1998). The CPI allows the six variables to be related in a quantifiable manner that expresses the relative change-potential of the coast to physical changes due to future sea-level change. This method yields numerical data that cannot be equated 
directly with particular physical effects. It does, however, highlight areas where the various effects of sea-level change may be the greatest. Once each section of coastline is assigned a changepotential value for each specific data variable, the coastal change-potential index (CPI) is calculated as the square root of the product of the ranked variables divided by the total number of variables;

$$
C P I=\frac{\sqrt{a \times b \times c \times d \times e \times f}}{6}
$$

where, $\mathrm{a}=$ geomorphology, $\mathrm{b}=$ shoreline erosion/accretion rate, $\mathrm{c}=$ coastal slope, $\mathrm{d}=$ relative sealevel rise rate, $\mathrm{e}=$ mean significant wave height, and $\mathrm{f}=$ mean tide range. The calculated CPI value is then divided into quartile ranges to highlight different change-potentials within the park. The CPI ranges (low - very high) reported here apply specifically to GBNPP, and are not comparable to CPI ranges in other parks where the CPI has been employed (i.e., very high change-potential means the same among parks; it's the numeric values that differ, such that a numeric value that equals very high change-potential in one park may equal moderate change-potential in another). To compare change-potential between coastal parks, the national-scale studies should be used (Thieler and Hammar-Klose, 1999, 2000a, and 2000b). We feel this approach best describes and highlights the coastal change-potential specific to each park.

\section{Results}

The CPI values calculated for GBNPP range from 1.83 - 28.28. The mean CPI value is 5.8; the mode and the median is 3.16 . The standard deviation is 5.03 . The 25 th, 50 th, and 75 th percentiles are 2.6, 3.5 and 8.0, respectively.

Figure 13 shows a map of the coastal change-potential index for GBNPP. The CPI scores are divided into low, moderate, high, and very high change-potential categories based on the quartile ranges and visual evaluation of the data. CPI values below 2.6 are assigned to the low change-potential category. Values from 2.6 to 3.5 are considered moderate change-potential. High change-potential values lie between 3.51 and 8.0. CPI values above 8.0 are classified as very high change-potential. Figure 14 shows the percentage of GBNPP shoreline in each changepotential category. Nearly $1900 \mathrm{~km}$ (1,180 miles) of shoreline is evaluated along the GBNPP. Of this total, twenty-one percent of the mapped shoreline is classified as being at very high changepotential due to future sea-level change. Twenty-five is classified as high change-potential, twentyfour percent as moderate change-potential, and thirty percent as low change-potential.

\section{Discussion}

The data within the coastal change-potential index (CPI) show variability at different spatial scales (fig. 13). However, the ranked values for the physical process variables vary less over the extent of the shoreline. The value of the relative sea-level change variable is constant at very high change-potential for the entire study area. The significant wave height values are ranked as very low within the fjords to very high along the open coast of the Gulf of Alaska. The tidal range variable is ranked as moderate $(2.0-4.0 \mathrm{~m})$ to low $(4.01-6.0 \mathrm{~m})$ change-potential for Glacier Bay proper.

The geologic variables show the most spatial variability and thus have the most influence on CPI variability (fig. 13). Geomorphology in the park includes very high change-potential tidewater glacier termini, high change-potential gravel beaches, moderate change-potential alluvial fans and glacial features, low and very low change-potential rock and cliff features (fig. 6 A-I and fig. 7). 
Change-potential assessment based on shoreline change is moderate with two small areas of low change-potential and a few small areas of high change-potential (fig. 8). Regional coastal slope is in the very low to very high change-potential range for GBNPP (fig. 9).

The most influential variables in the CPI are geomorphology, shoreline change, coastal slope, and wave energy; therefore they may be considered the dominant factors controlling how GBNPP will evolve as sea level changes.

\section{Conclusions}

The coastal change-potential index (CPI) provides insight into the relative potential of coastal change due to future sea-level change. The maps and data presented here can be viewed in at least two ways:

1. as an indication of where physical changes are most likely to occur as sea level continues to change; and

2. as a planning tool for the GBNPP.

As ranked in this study, geomorphology, regional coastal slope, wave energy, and mean tidal range are the most important variables in determining the CPI for GBNPP. GBNPP preserves a dynamic natural environment, which must be understood in order to be managed properly. The CPI is one way that park managers can assess objectively the natural factors that contribute to the evolution of the coastal zone, and thus how the park may evolve in the future. 


\section{References}

Connor, C. and O'Haire, D., 1988, Roadside Geology of Alaska: Mountain Press Publishing Co., Missoula, Montana, $251 \mathrm{p}$.

Douglas, B.C., 1997, Global sea change, A redetermination: Surveys in Geophysics, v. 18, p. 279292.

Geiselman, J., Dunlap, J., Hooge, P., and Albert, eds., 1997, Glacier Bay Ecosystem GIS CD-ROM set: US Geological Survey and Interrain Pacific, Anchorage and Juneau, Alaska, 2 CD-ROM volumes. Also available online at http://www.inforain.org/alaska/glabaycd/.

Gornitz, V. and White, T.W., 1992, A coastal hazards database for the U.S. West Coast: ORNL/CDIAC-81, NDP-043C, Oak Ridge National Laboratory, Oak Ridge, Tenn.

Gornitz, V.M., Daniels, R.C., White, T.W., and Birdwell, K.R., 1994, The development of a coastal vulnerability assessment database; Vulnerability to sea-level change in the U.S. southeast:

Journal of Coastal Research, Special Issue No. 12, p. 327-338.

Hammar-Klose, E.S., and Thieler, E.R., 2001, Coastal Vulnerability to Sea-Level Rise, A Preliminary Database for the U.S. Atlantic, Pacific, and Gulf of Mexico Coasts: U.S. Geological Survey, Digital Data Series, DDS-68, CD-ROM. Also available online at http://pubs.usgs.gov/dds/dds68/.

Hassan, M.A., and Klein, M., 1999, Fluvial adjustment of the Lower Jordan River to a drop in the Dead Sea level: Geomorphology, v. 45, no. 1-2, p. 21-33.

IPCC, 2002, Climate Change 2001, The Scientific Basis; Contribution of Working Group I to the Third Assessment Report of the Intergovernmental Panel on Climate Change: IPCC: Geneva, Switzerland, 563 p. Also available online at http://www.ipcc.ch.

Larsen, C.F., Echelmeyer, K.A., Freymueller, J.T., and Motyka, R.J., 2003, Tide gauge records of uplift along the northern Pacific-North American plate boundary, 1937 to 2001: Journal of Geophysical Research, v. 108, no B4, p. 2216-2231.

Larsen, C.F., Motyka, R.J., Freymueller, J.T., Echelmeyer, K.A., Ivins, E.R., 2005, Rapid viscoelastic uplift in southeast Alaska caused by post-Little Ice Age glacial retreat: Earth and planetary Science letters, v. 237, p. 548-560.

Larsen, N.D., Uplift rates in southeast Alaska. Web page at http://www.aeic.alaska.edu/input/chris/. Accessed Sept. 2006.

Manley, W., 2002, Maximum Pleistocene glacier extents, Alaska PaleoGlacier Atlas: GIS data. Web page at http://instaar.colorado.edu/QGISL/data_intro.html. Accessed Sept. 2006

Mason, O., Neal, W.J., Pilkey, O.H., Bullock, J., Fathauer, T., Pilkey, D., and Swanston, D., 1997, Living with the Coast of Alaska: Duke University Press, Durham, North Carolina, 348 p. 
Molnia, B.F., 1986, Late Wisconsin glacial history of the Alaska continental margin, in T.D. Hamilton, T.M. Reed, and R.M. Thorson, eds., Glaciation in Alaska, the geologic record: Geologic Society of Alaska, Anchorage, Alaska, p 219-236.

National Research Council, 1990, Managing Coastal Erosion, Washington: National Academy Press, 163 p.

National Research Council, 1995, Beach Nourishment and Protection, Washington: National Academy Press, 334 p.

NOAA, 2005, Tidal station locations and ranges. Web page at http://coops.nos.noaa.gov/tides05/tab2wc2b.html. Accessed Sept. 2006.

Pilkey, O.H., and Davis, T.W., 1987, An analysis of coastal recession models, North Carolina coast, in Nummedal, D., Pilkey, O.H., and Howard, J.D., eds., Sea-level Fluctuation and Coastal Evolution: SEPM (Society for Sedimentary Geology) Special Publications no. 41, Tulsa, Okla., p. 59-68.

PSMSL, 2005, Permanent Service for Mean Sea Level. Web page at http://www.pol.ac.uk/psmsl/ Accessed Sept. 2006.

Shaw, J., Taylor, R.B., Forbes, D.L., Ruz, M.H., and Solomon, S., 1998, Sensitivity of the Canadian coast to sea-level change: Geological Survey of Canada Bulletin 505, 114 p.

Thieler, E.R., and Hammar-Klose, E.S., 1999, National Assessment of Coastal Vulnerability to Sea-Level Rise, U.S. Atlantic Coast: U.S. Geological Survey Open-File Report 99-593, 1 sheet. Also available online at http://pubs.usgs.gov/of/of99-593/.

Thieler, E.R., and Hammar-Klose, E.S., 2000a, National Assessment of Coastal Vulnerability to Sea-Level Rise, U.S. Pacific Coast: U.S. Geological Survey Open-File Report 00-178, 1 sheet. Also available online at http://pubs.usgs.gov/of/of00-178/.

Thieler, E.R., and Hammar-Klose, E.S., 2000b, National Assessment of Coastal Vulnerability to Sea-Level Rise, U.S. Gulf of Mexico Coast: U.S. Geological Survey Open-File Report 00-179, 1 sheet. Also available online at http://pubs.usgs.gov/of/of00-179/

U.S. Global Change Research Program, 2000, U.S. National assessment of the potential consequences of climate variability and change, Washington, D.C.: U.S. Climate Change Science Program/U.S. Global Change Research Program.

Zervas, C., 2001, Sea Level Variations of the United States 1854-1999: NOAA Technical Report NOS CO-OPS 36, 201 p. 


\section{Figures}

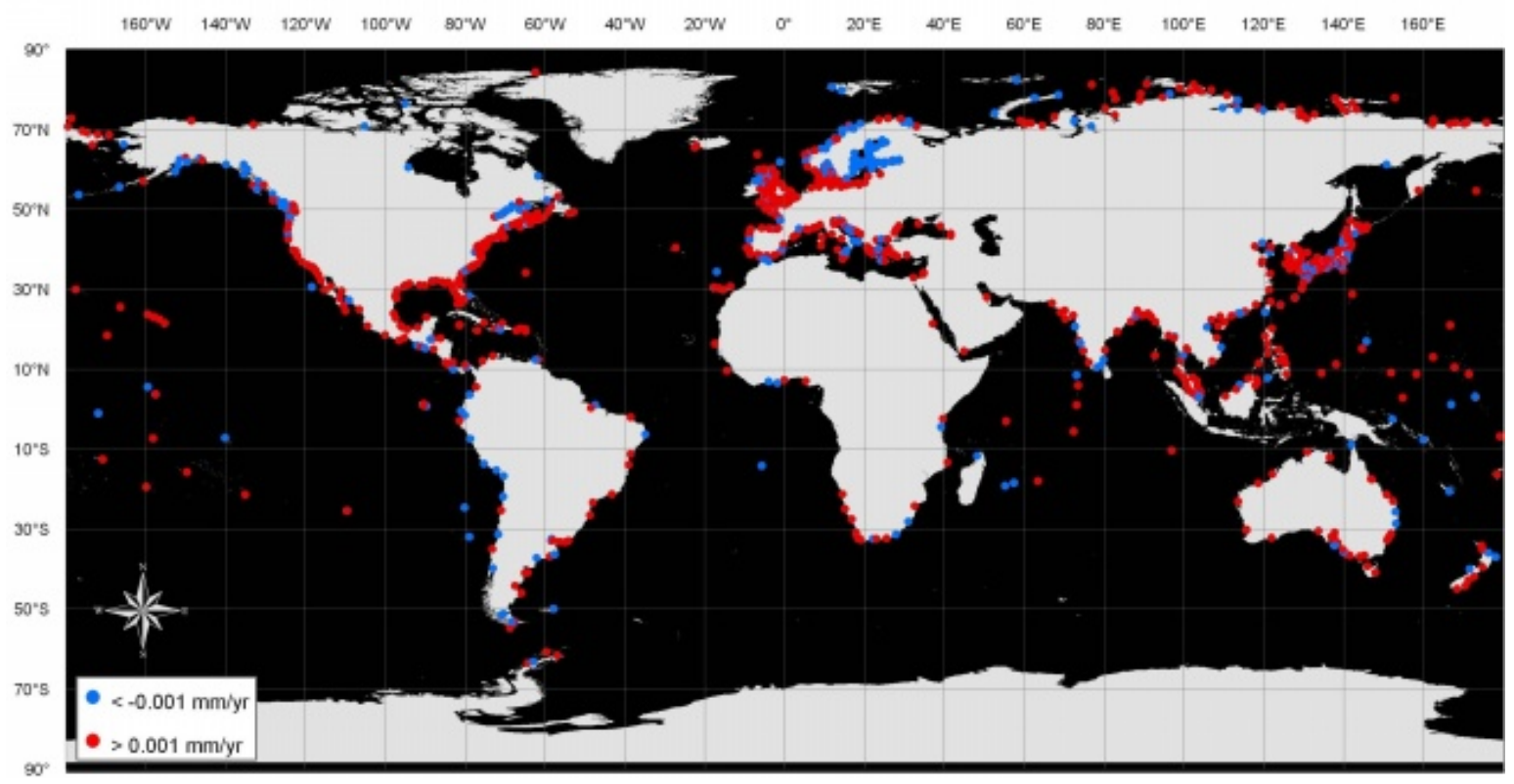

Figure 1. Global distribution of water-level recording stations as reported by the Permanent Service for Mean Sea Level (PSMSL, 2005). Red dots indic ate relative increase in sea-level, blue dots indicate a relative decrease in sea-level. Nearly three-quarters of the stations report an increase in sea-level relative to the land surface. 


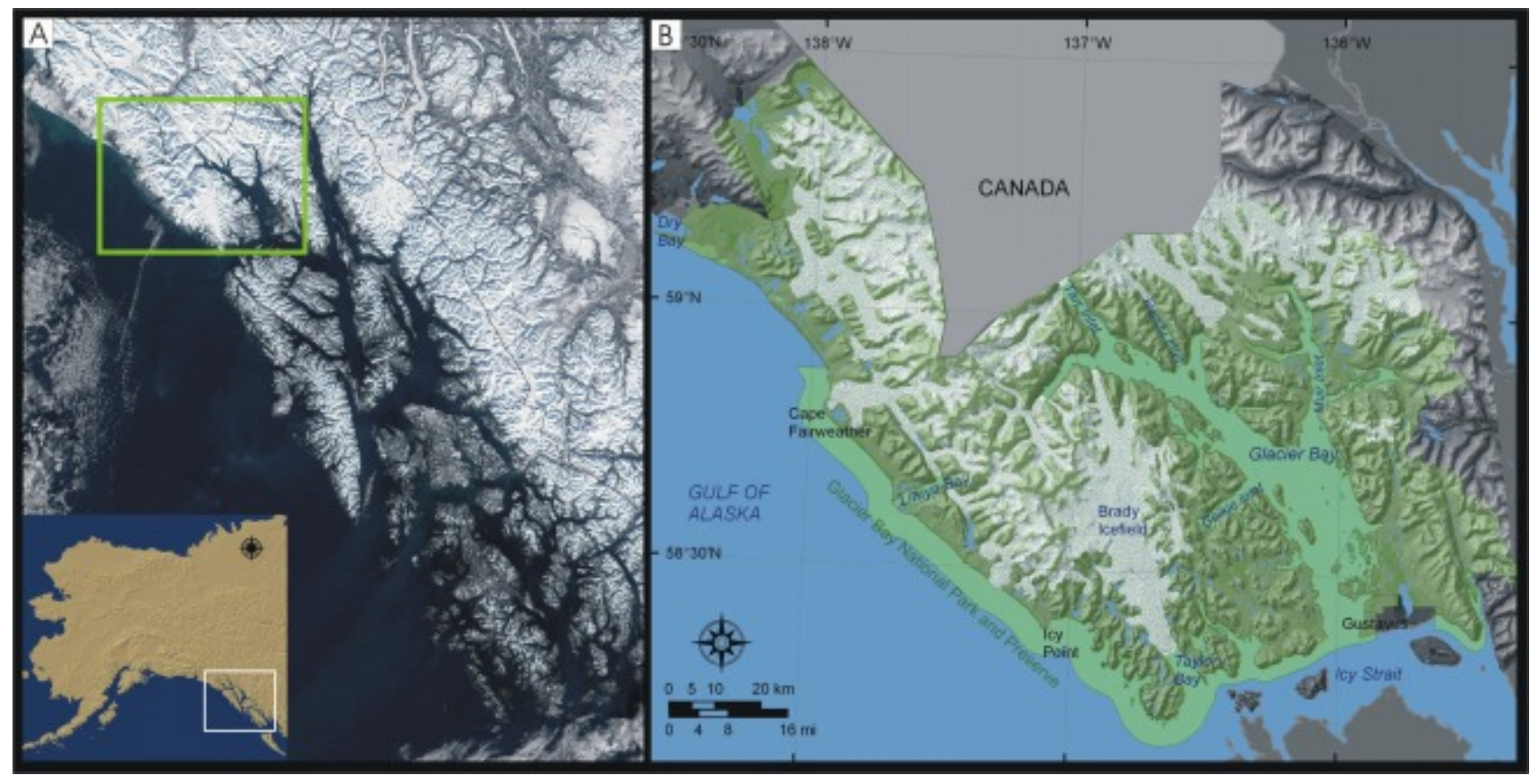

Figure 2. Location of Glacier Bay National Park and Preserve in southeast Alaska. A) MODIS satellite image of the Alexander Archipelago (image from Jacques Descloitres, NASA/GSFC, 2002), the green box is indicating the location of Glacier Bay National Park and Preserve, and B) Glacier Bay National Park and Preserve. A more detailed map is provided by the National Park Service and can be viewed in digital format at http://home.nps.gov/applications/parks/glba/ppMaps/ACF30C1.pdf. 


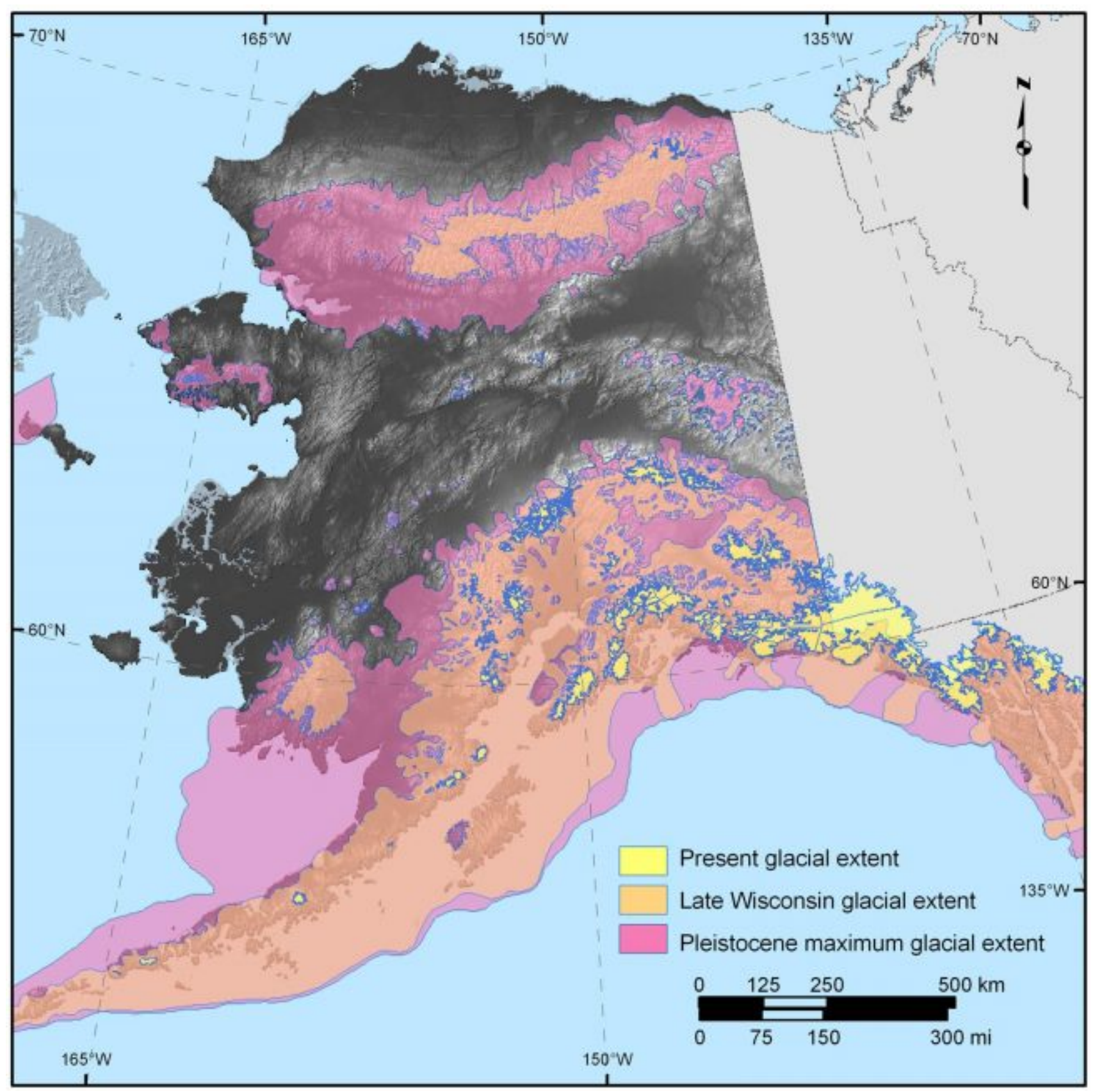

Figure 3. Maximum extent of Pleistocene glaciations and present-day glaciers in Alaska. Data from the Alaska PaleoGlacier Atlas (Manley, 2002). 


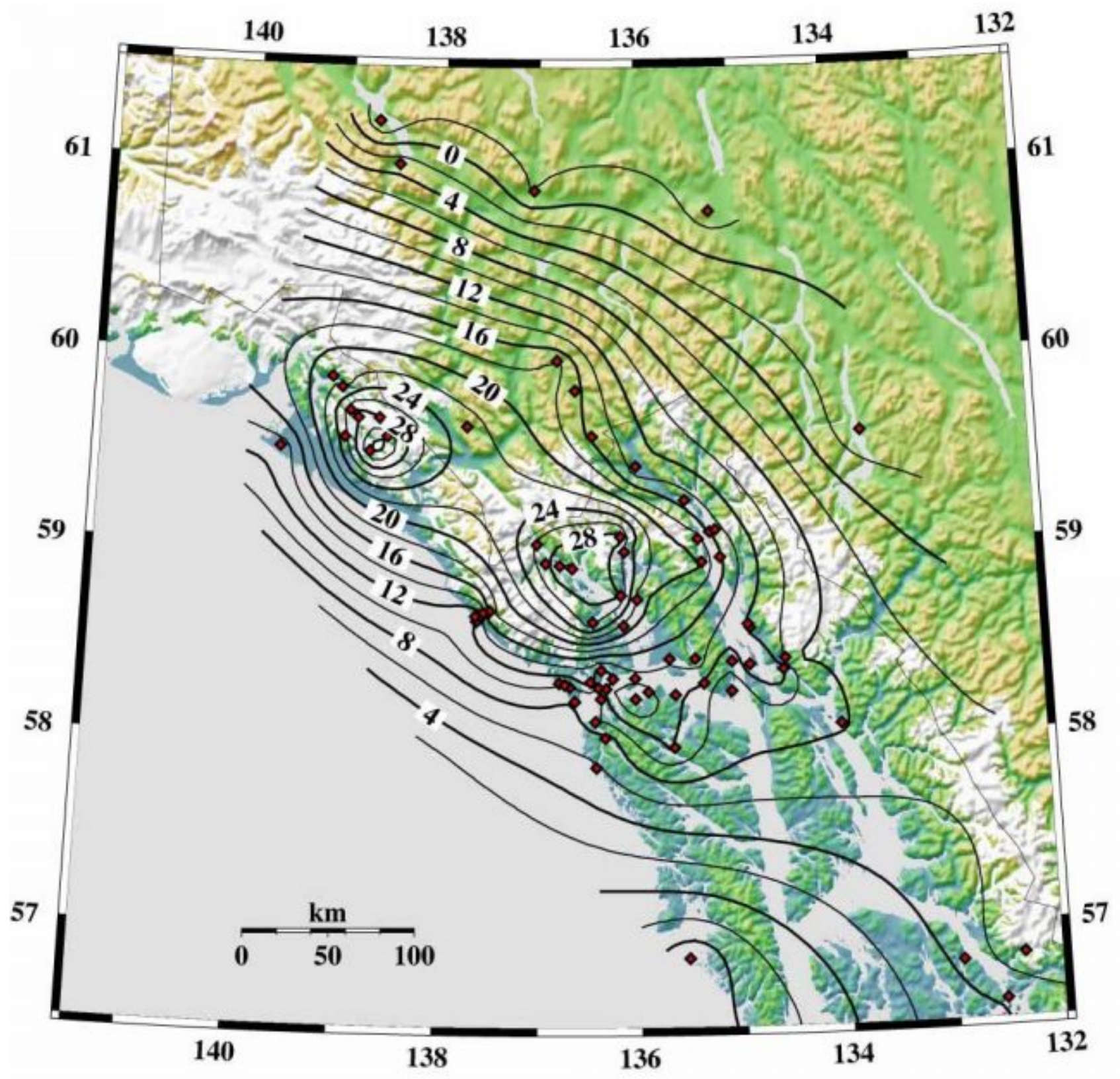

Figure 4. Uplift rates from GPS measurements as determined by Larsen and others (2003-2005). Measurements are in $\mathrm{mm} / \mathrm{yr}$. Figure from Larsen and others (2005). See also author's Web site at http://www.aeic.alaska.edu/input/chris/. 


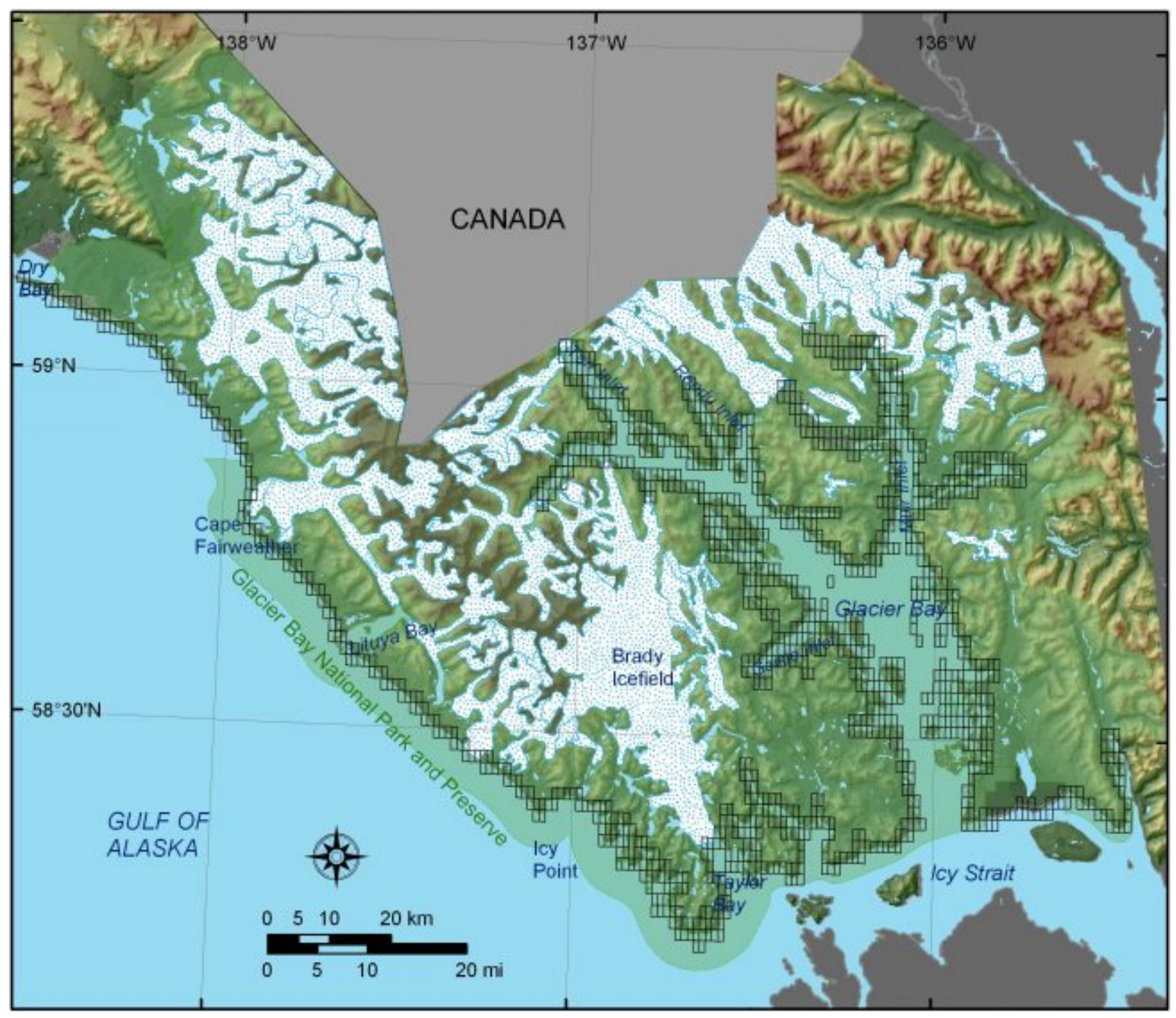

Figure 5.Shoreline grid for Glacier Bay National Park and Preserve. Each cell is approximately 1minute of shoreline and represents a shoreline segment for which each variable is defined. 


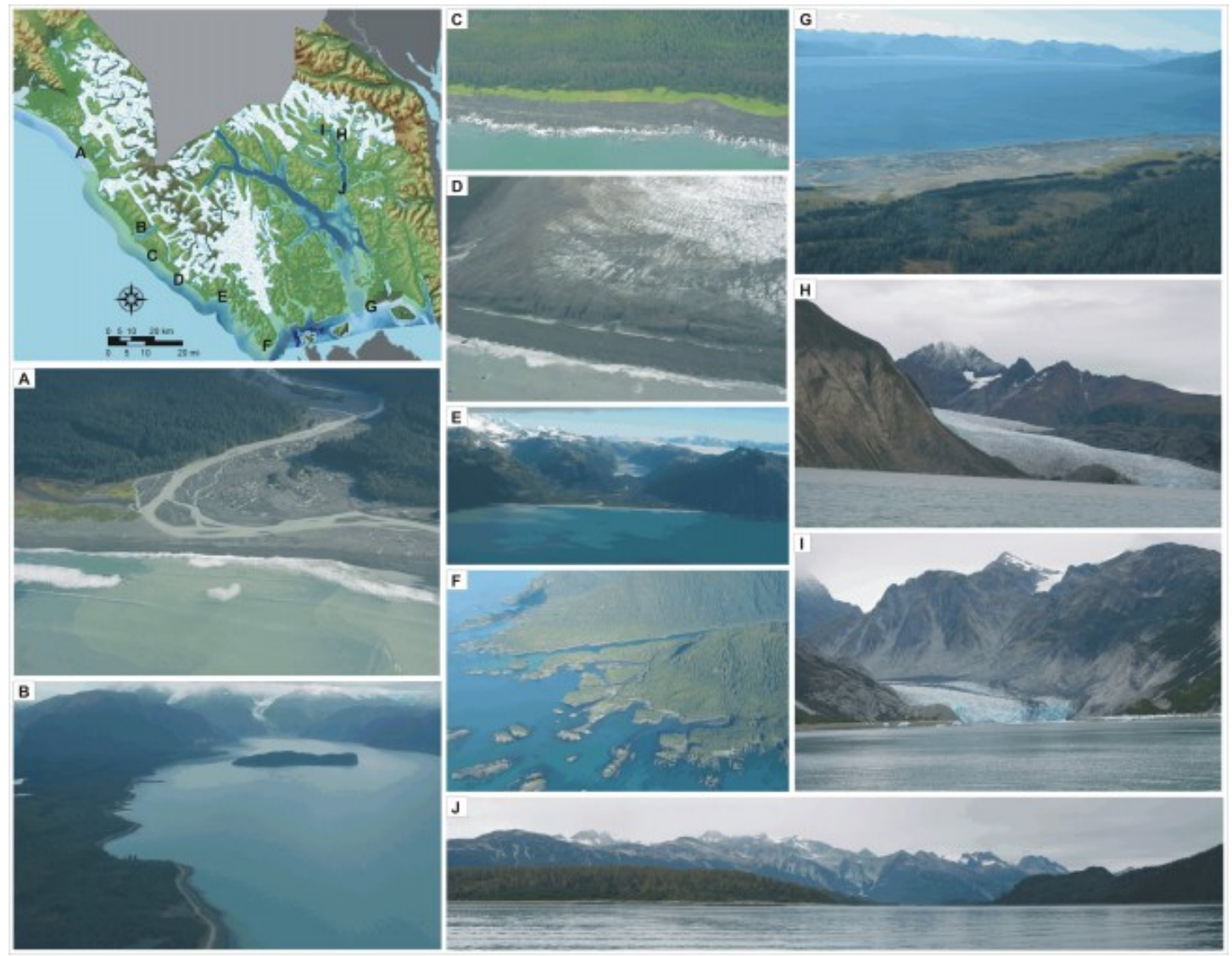

Figure 6. Photos of landforms within GBNPP. The figure in the upper left is indicating the approximate location of photos $A-J$. A) This is a high change-potential gravel beach shoreline north of Cape Fairweather. B) The sides of Lituya Bay were ranked as moderate change-potential because they are composed of alluvium and glacial deposits. C) A small section of coast between Lituya Bay and LaPerouse Glacier is rocky, and thus ranked as low change-potential. D) Laperouse is a tidewater glacier along the Gulf of Alaska coast, very high change-potential. E) An alluvium filled valley within Palma Bay is moderate change-potential while the high cliffs on either side are ranked as very low change-potential. F) The shoreline near Cape Spencer is ranked as low to very low change-potential based on the height of the cliffs. G) The Gustavus outwash plain was ranked as high change-potential because wave and tidal currents here rework the sediments along this area. H) Riggs glacier (very high change-potential) in Muir Inlet is bound on its north side by very low change-potential rock cliffs. I) McBride glacier is very high change-potential surrounded by moderate change-potential moraines and low change-potential cliffs. J) Moraines (moderate change-potential) near the entrance to Muir Inlet were deposited in the late 19th century as Muir Glacier retreated up the inlet some $35 \mathrm{~km}$. A map with location names is provided by the National Park Service and can be viewed in digital format at: http://home.nps.gov/applications/parks/glba/ppMaps/ACF30C1.pdf. 


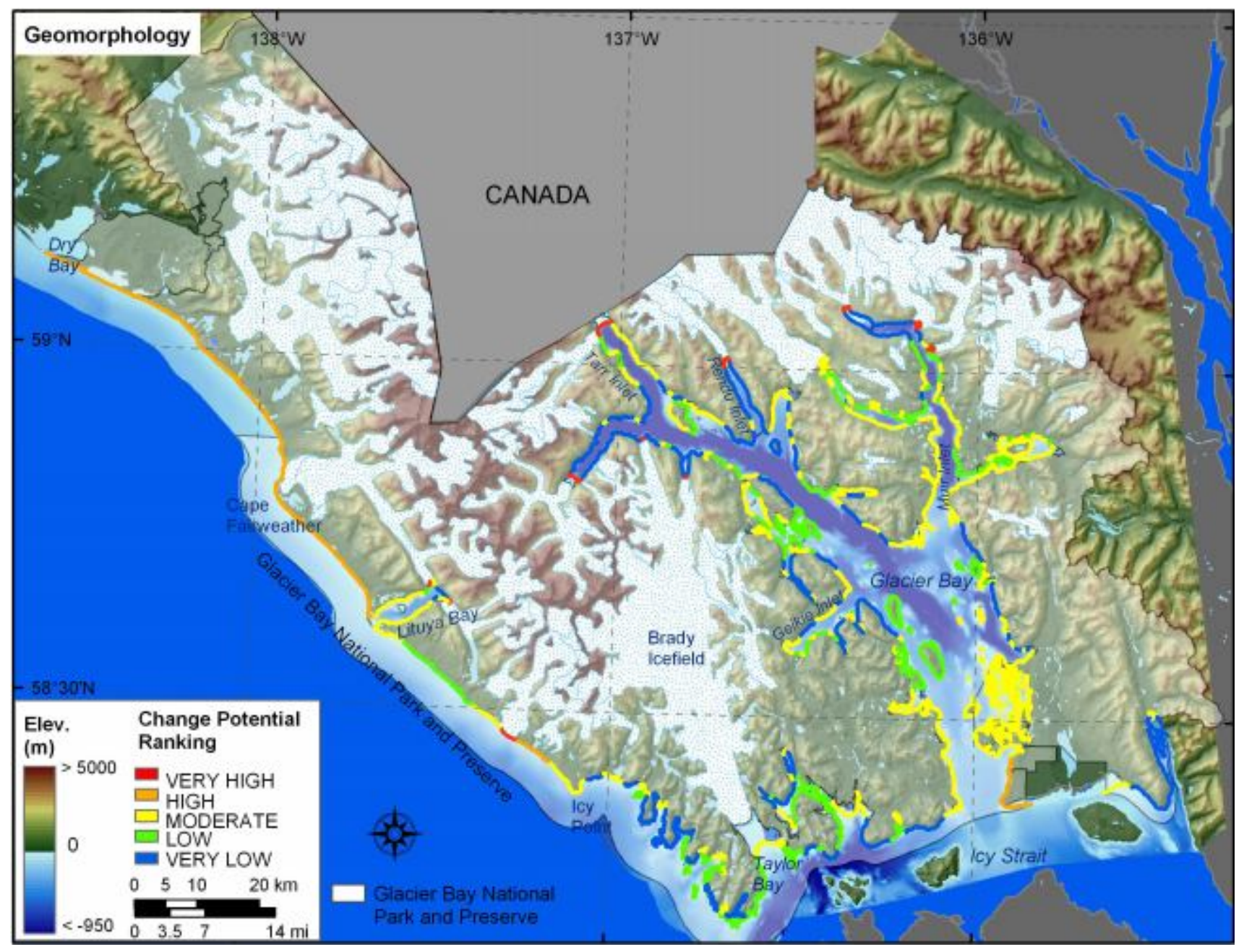

Figure 7. Coastal Geomorphology for GBNPP. The colored shoreline represents the variations in coastal geomorphology within the park. The very high change-potential geomorphology is tidewater glacier termini. High change-potential geomorphology includes gravel and cobble beaches or reworked outwash material. Moderate change-potential geomorphology consists of alluvial fans and glacial deposits along the shore. Low change-potential geomorphology includes medium cliffs and rock platforms, and very low change-potential areas consist of steep rock cliffs. 


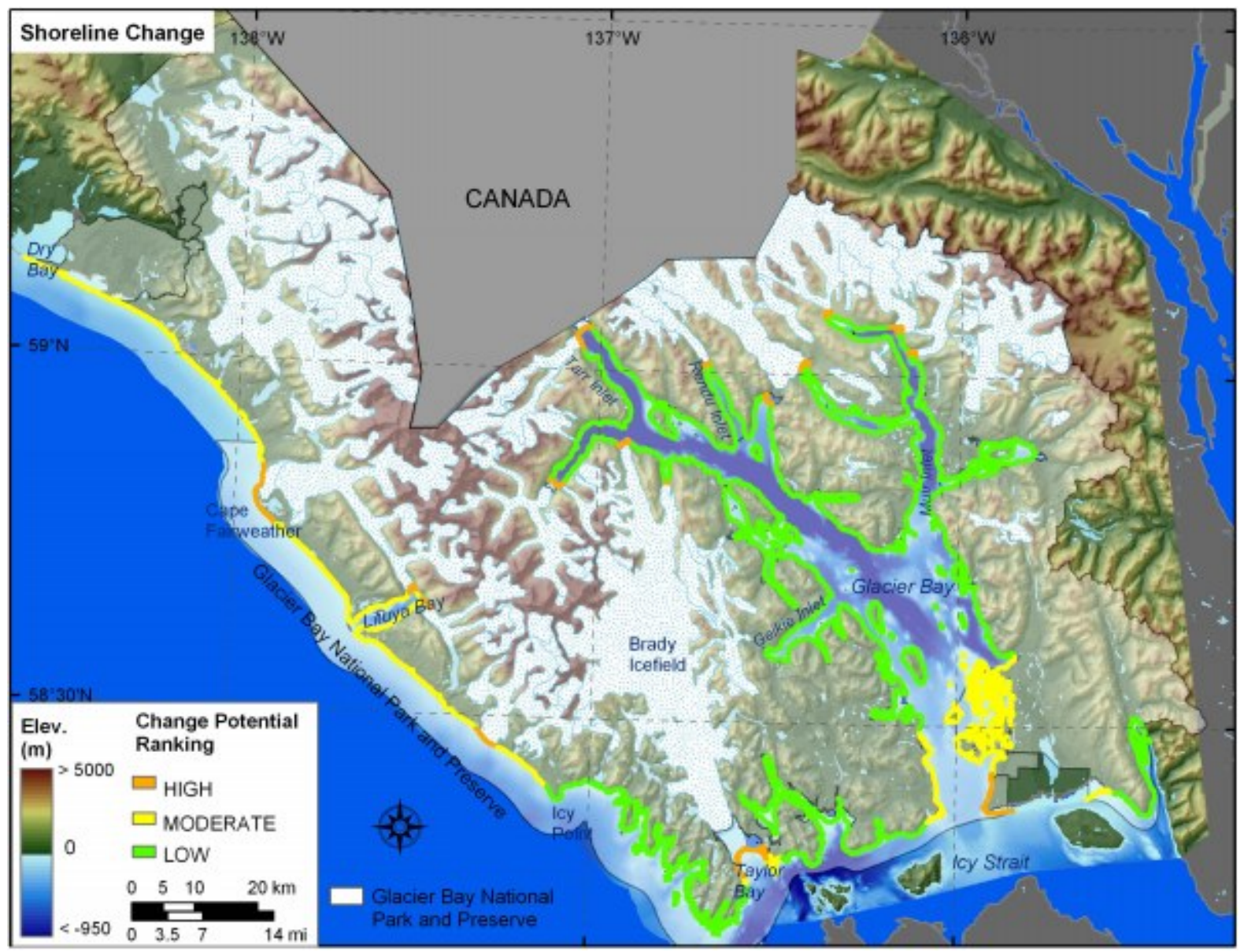

Figure 8. Estimated shoreline change-potential for GBNPP. The colored shoreline represents the estimated shoreline change-potential. Two areas of historic sediment accretion are identified at Taylor Bay and Gustavus; other areas of high shoreline change-potential are at or near glacier termini. The unconsolidated areas of the outer coast were ranked as moderate shoreline changepotential, and rocky cliffs were ranked as low shoreline change-potential. 


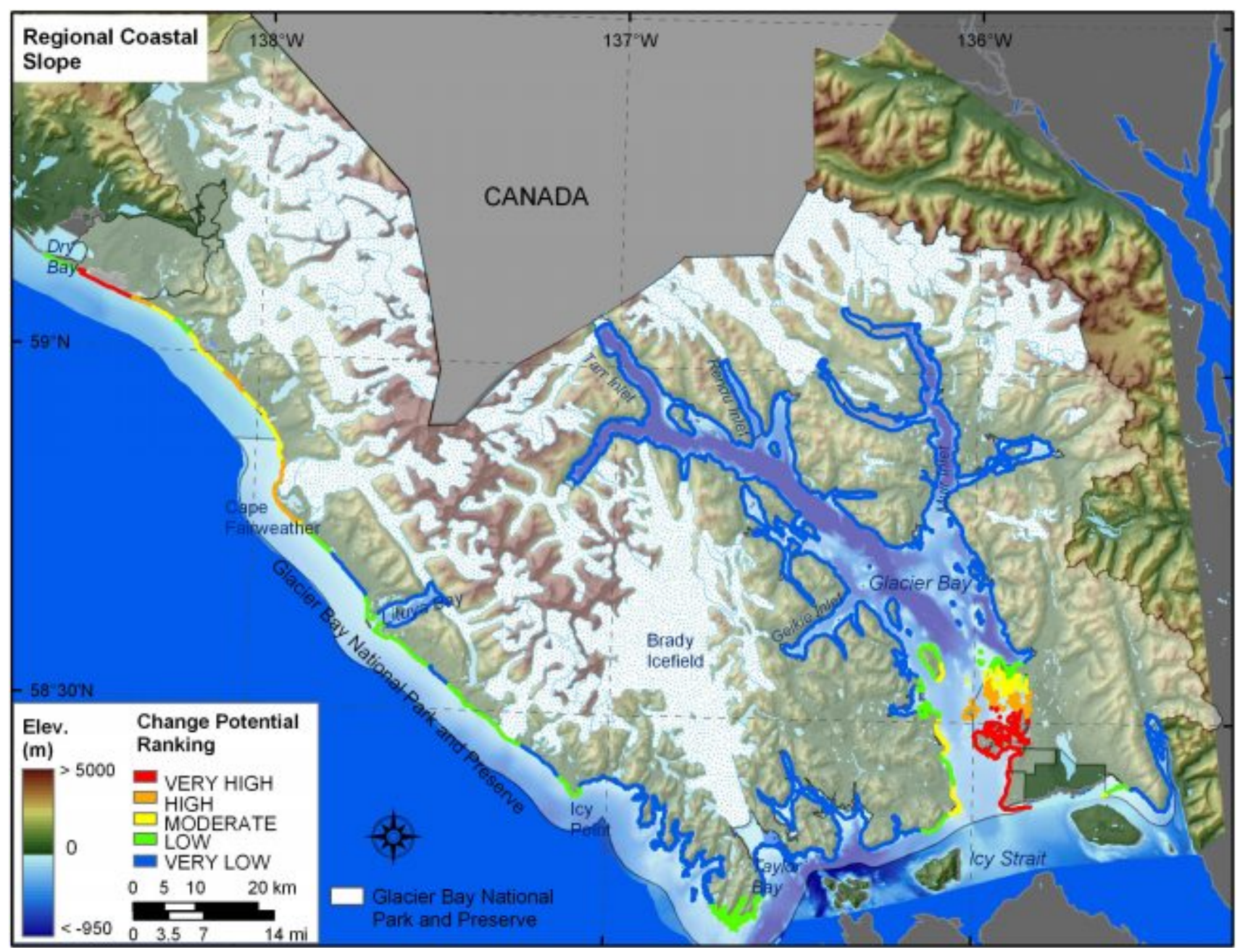

Figure 9. Regional coastal slope for GBNPP. The colored shoreline represents the regional slope of the land, $10 \mathrm{~km}$ landward and seaward of the shoreline. Very low change-potential coastal slope areas are where high mountains are adjacent to deep fjords. Coastal slopes become shallower and thus higher change-potential along the outer coast in the Gulf of Alaska and at the entrance to Glacier Bay where there is low elevation outwash material. 


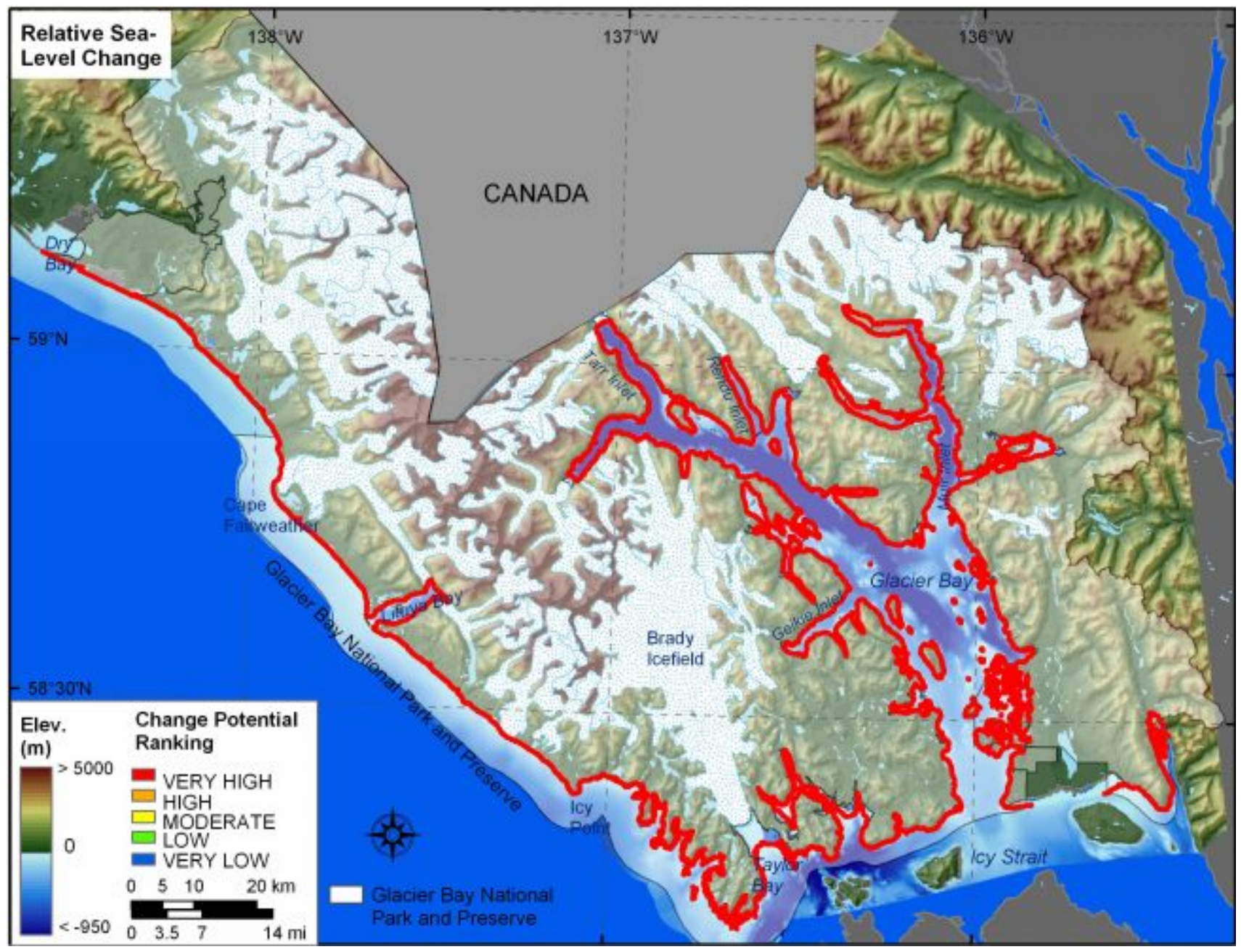

Figure 10. Rate of relative sea-level change for GBNPP. The colored shoreline represents the ranked rate of change for Yakutat, $A K$, located $75 \mathrm{~km}$ northwest of the park boundary at Dry Bay. All of GBNPP is ranked as very high change-potential with respect to relative sea-level change. 


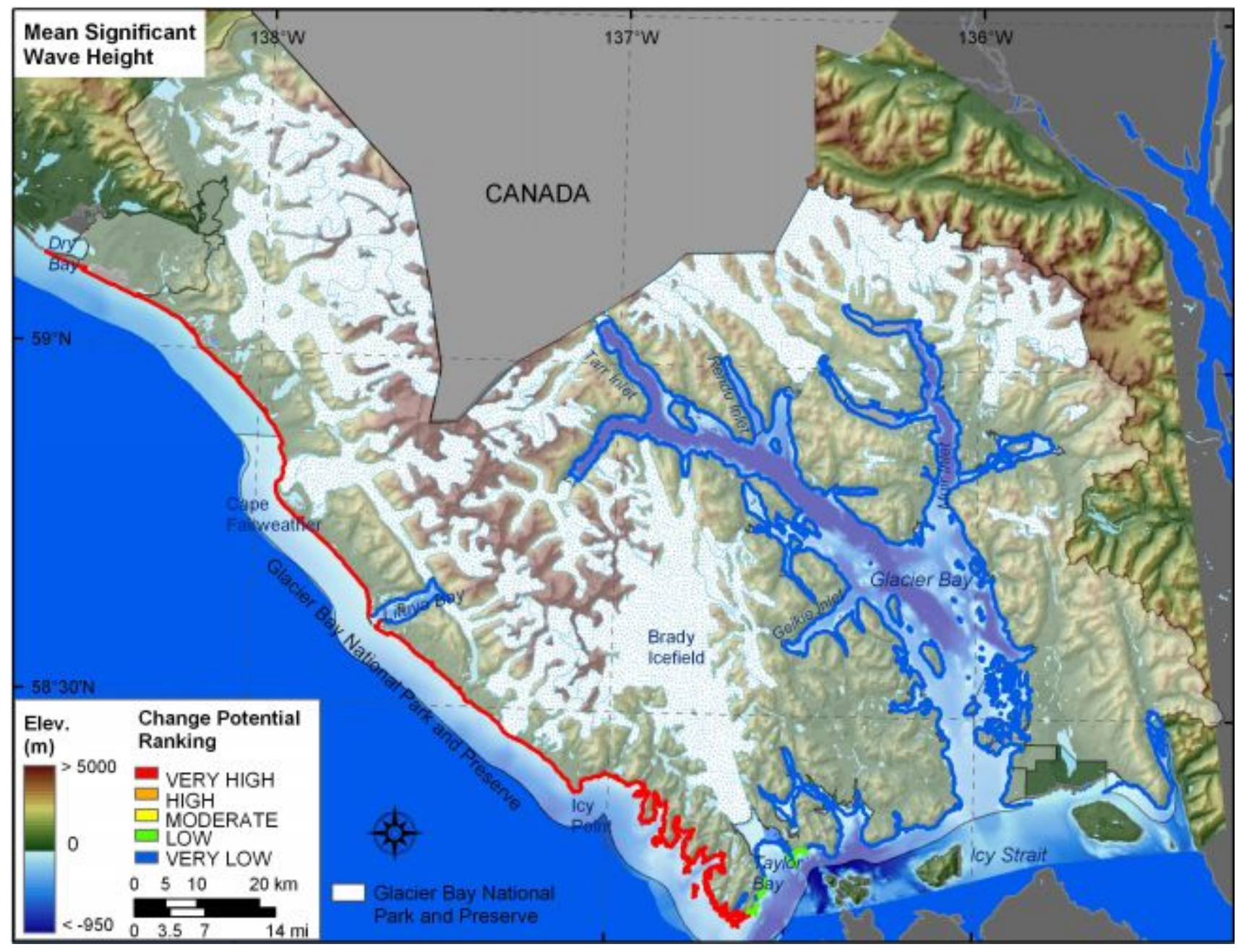

Figure 11. Mean significant wave heights for GBNPP. The colored shoreline represents the ranked means significant wave heights within the park. Very high wave energy areas are located along the open coast of the Gulf of Alaska. Wave energy decreases as distance into the fjords increases, or where the shoreline is protected from direct wave approach. 


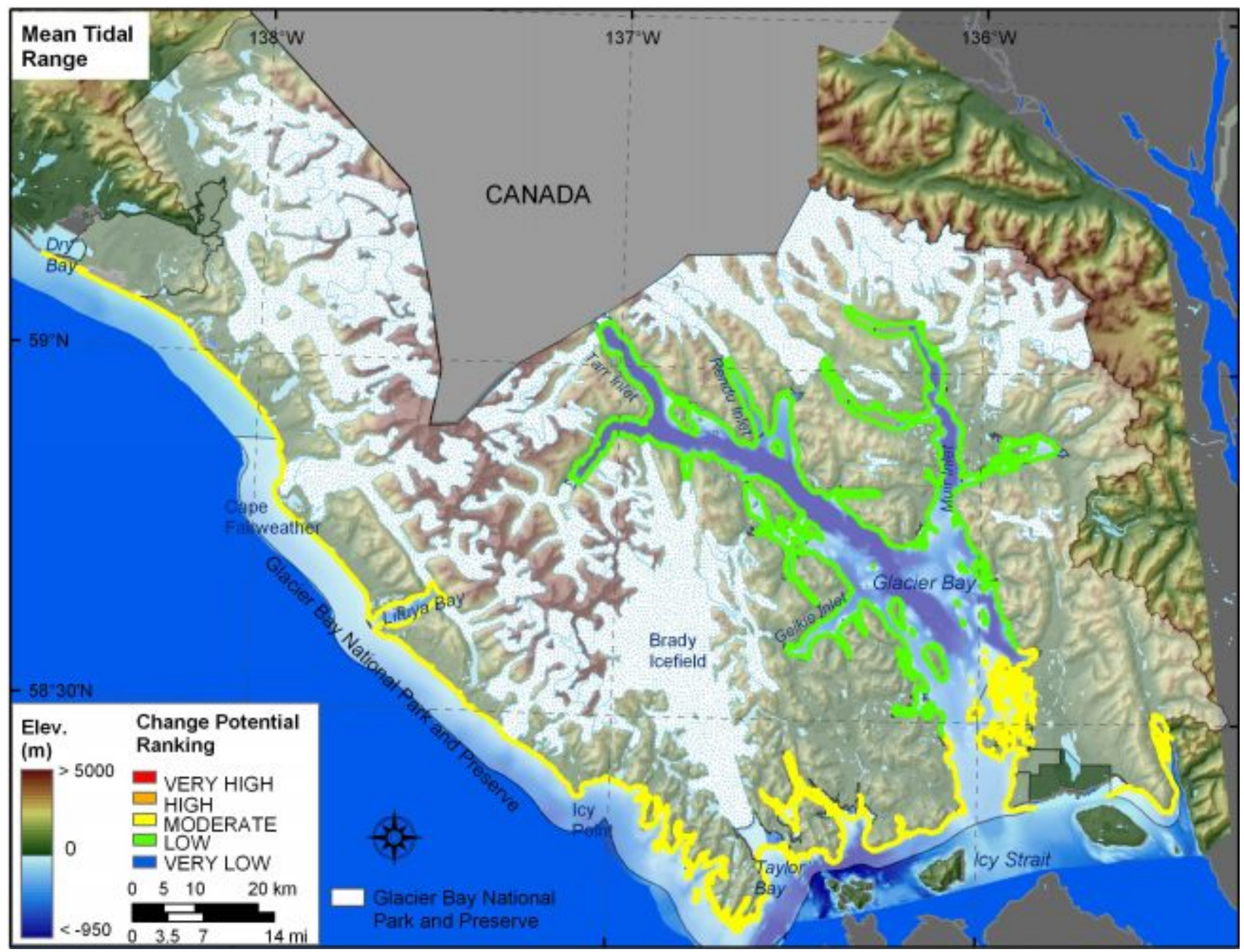

Figure 12. Mean Tidal Range for GBNPP. The colored shoreline represents the ranked mean tidal range for GBNPP. GBNPP is ranked as moderate to low change-potential with respect to tidal range. 


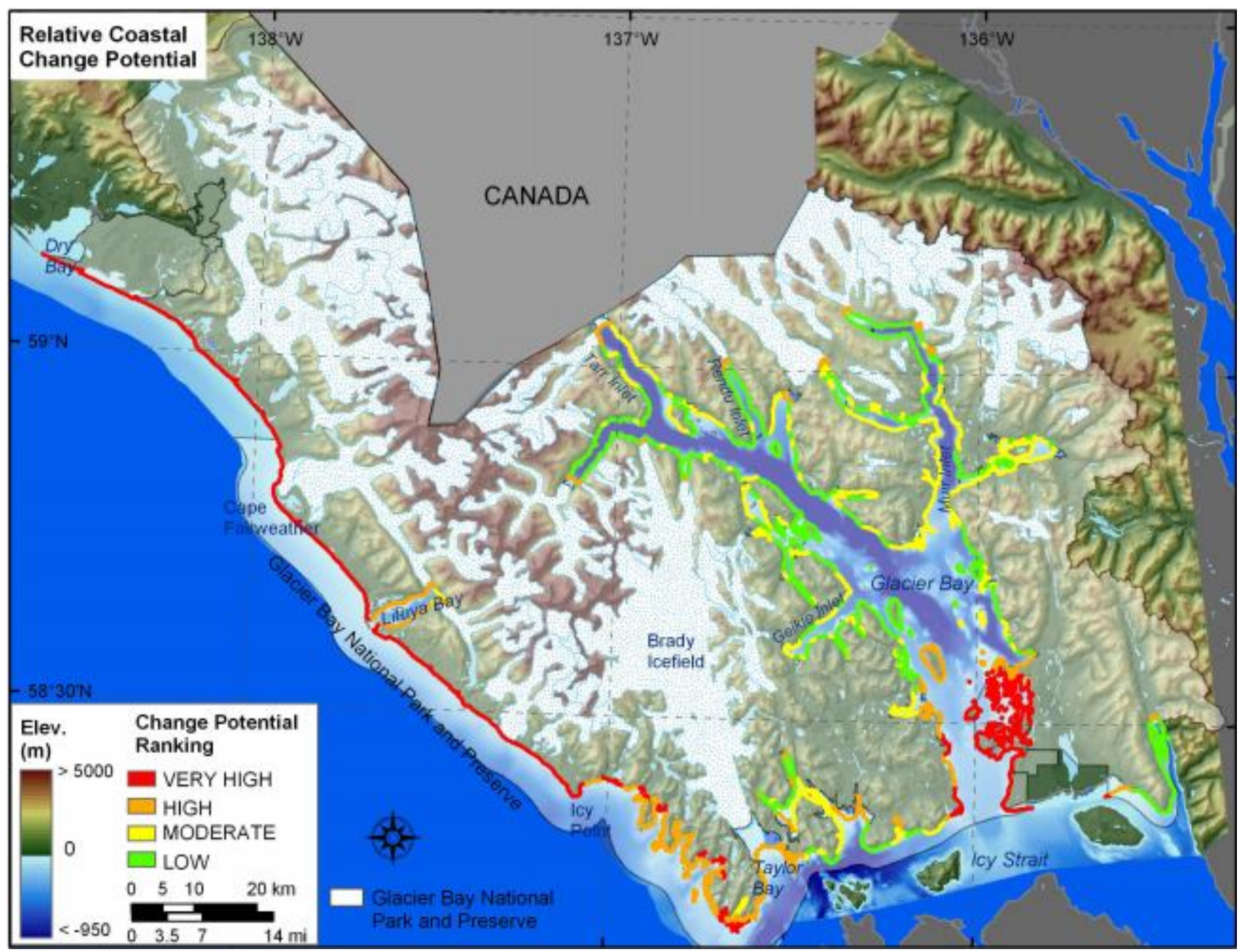

Figure 13. Relative Coastal Change-Potential for GBNPP. The colored shoreline represents the relative coastal change-potential index (CPI) determined from the six variables. The very high change-potential shoreline is located along the outer coast where significant wave heights are high and coastal slopes are low. High change-potential shoreline exists at tidewater glacier termini within the fjords and areas along Bartlett Cove where there are large amounts of unconsolidated outwash material. Moderate change-potential shoreline generally lies within Glacier Bay in areas of alluvium or glacial deposits. The low change-potential shoreline is located along rocky areas and sheltered locations in the fjords 


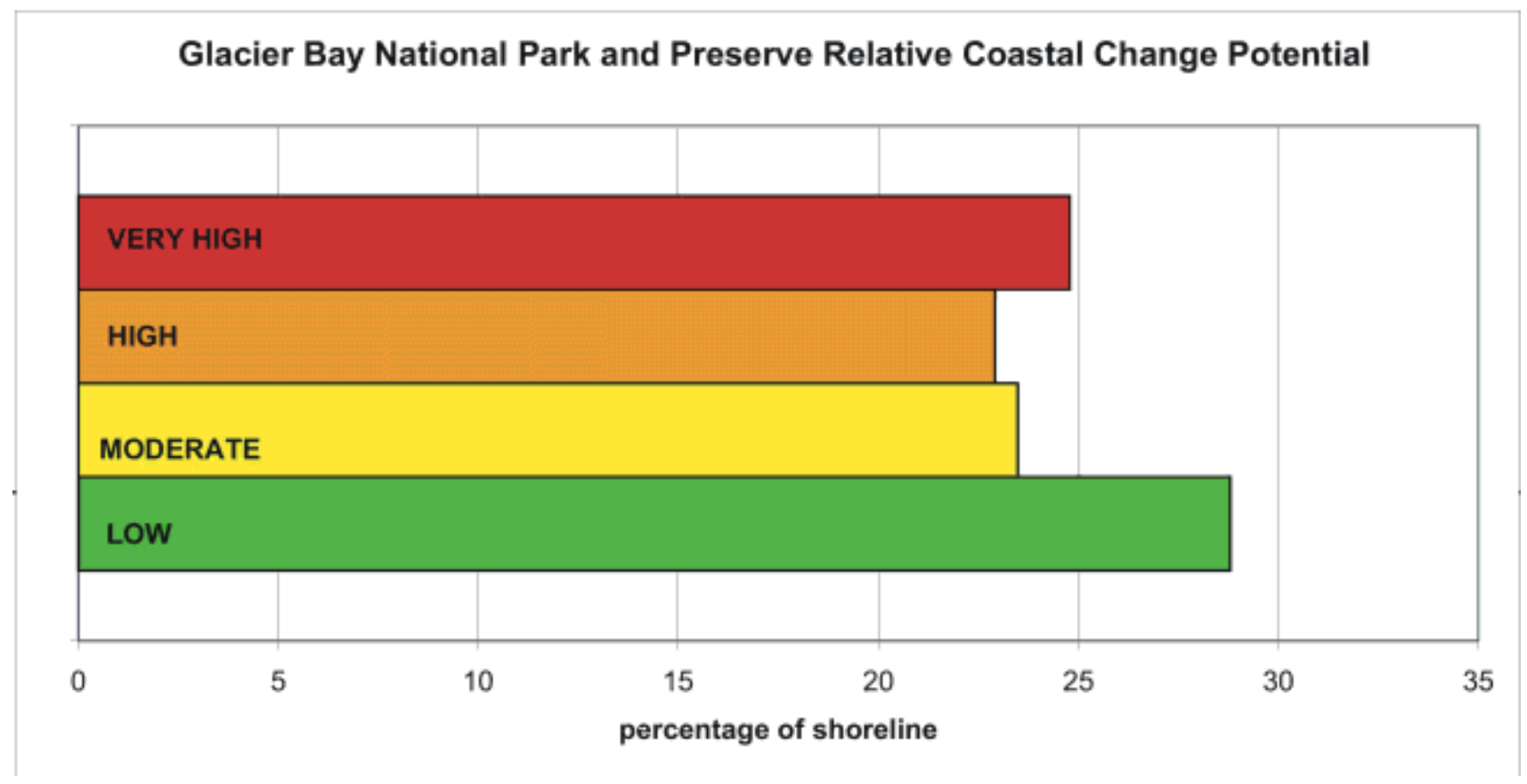

Figure 14. Percentage of Glacier Bay National Park and Preserve shoreline in each CPI category. 


\section{Tables}

Table 1: Ranges for Vulnerability Ranking of Variables on the U.S. Pacific Coast.

\begin{tabular}{|c|c|c|c|c|c|}
\hline Variable & $\begin{array}{c}\text { Very Low } \\
1\end{array}$ & $\begin{array}{l}\text { Low } \\
2\end{array}$ & $\begin{array}{c}\text { Moderate } \\
3\end{array}$ & $\begin{array}{l}\text { High } \\
4\end{array}$ & $\begin{array}{c}\text { Very High } \\
5\end{array}$ \\
\hline GEOMORPHOLOGY & $\begin{array}{l}\text { Rocky cliffed } \\
\text { coasts, Fjords }\end{array}$ & $\begin{array}{l}\text { Medium cliffs, } \\
\text { Indented } \\
\text { coasts }\end{array}$ & $\begin{array}{l}\text { Low cliffs, } \\
\text { Glacial drift, } \\
\text { Alluvial plains }\end{array}$ & $\begin{array}{l}\text { Cobble Beaches, } \\
\text { Estuary, Lagoon }\end{array}$ & $\begin{array}{l}\text { Barrier beaches, Sand } \\
\text { beaches, Salt marsh, } \\
\text { Mud flats, Deltas, } \\
\text { Mangrove, Coral reefs }\end{array}$ \\
\hline $\begin{array}{l}\text { SHORELINE EROSION/ } \\
\text { ACCRETION (m/yr) }\end{array}$ & N/A & $\begin{array}{l}\text { Change Not } \\
\text { Likely }\end{array}$ & $\begin{array}{l}\text { Change may or } \\
\text { may not occur }\end{array}$ & Change likely & N/A \\
\hline COASTAL SLOPE (\%) & $>14.7$ & $10.90-14.69$ & $7.75-10.89$ & $4.60-7.74$ & $<4.59$ \\
\hline $\begin{array}{l}\text { RELATIVE SEA-LEVEL } \\
\text { CHANGE (mm/yr) }\end{array}$ & $0-1.8$ & $1.8-2.5$ & $2.5-3.0$ & $3.0-3.4$ & $>3.4$ \\
\hline $\begin{array}{l}\text { MEAN WAVE HEIGHT } \\
(\mathrm{m})\end{array}$ & $<1.1$ & $1.1-2.0$ & $2.01-2.25$ & $2.26-2.6$ & $>2.6$ \\
\hline MEAN TIDE RANGE (m) & $>6.0$ & $4.0-6.0$ & $2.0-4.0$ & $1.0-2.0$ & $<1.0$ \\
\hline
\end{tabular}




\section{Table 2: Sources of Data}

\begin{tabular}{|c|c|c|}
\hline Variables & Source & $\begin{array}{c}\text { URL } \\
\text { (Not all sources are downloadable) }\end{array}$ \\
\hline GEOMORPHOLOGY & $\begin{array}{l}\text { 1) Oblique aerial } \\
\text { photos, 2) Surficial } \\
\text { geology data from } \\
\text { USGS (Geiselman and } \\
\text { others, 1997). 3) B. } \\
\text { Molnia and A. Post } \\
\text { (personal } \\
\text { communication). }\end{array}$ & http://www.inforain.org/alaska/glabaycd/ \\
\hline $\begin{array}{l}\text { SHORELINE } \\
\text { EROSION/ACCRETION }\end{array}$ & $\begin{array}{l}\text { 1) Oblique aerial } \\
\text { photos, 2) field visit } \\
\text { and phone interview } \\
\text { with B. Molnia }\end{array}$ & none \\
\hline COASTAL SLOPE $(\%)$ & $\begin{array}{l}\text { 1) NGDC ETOPO2 } \\
\text { Global 2' Elevation 2) } \\
\text { 1:250,000 topo-data } \\
\text { based on USGS DEMs } \\
\text { and } 25 \mathrm{~m} \text { bathymetric } \\
\text { data from NOS } \\
\text { (Geiselman and others, } \\
\text { 1997) }\end{array}$ & $\begin{array}{l}\text { http://www.ngdc.noaa.gov/mgg/fliers/01mgg04.html } \\
\text { http://www.inforain.org/alaska/glabaycd/ }\end{array}$ \\
\hline $\begin{array}{l}\text { RELATIVE SEA-LEVEL } \\
\text { CHANGE (mm/yr) }\end{array}$ & $\begin{array}{l}\text { NOAA Technical } \\
\text { Report NOS CO-OPS } \\
\text { 36 SEA LEVEL } \\
\text { VARIATIONS OF } \\
\text { THE UNITED } \\
\text { STATES 1854-1999 } \\
\text { (Zervas, 2001) }\end{array}$ & http://www.co-ops.nos.noaa.gov/publications/techrpt36doc.pdf \\
\hline MEAN WAVE HEIGHT (m) & $\begin{array}{l}\text { NOAA National Data } \\
\text { Buoy Center }\end{array}$ & http://www.ndbc.noaa.gov/maps/Alaska.shtml \\
\hline MEAN TIDE RANGE (m) & $\begin{array}{l}\text { NOAA/NOS CO-OPS } \\
\text { Historical Water Level } \\
\text { Station Index }\end{array}$ & http://tidesonline.nos.noaa.gov/ \\
\hline
\end{tabular}

